\title{
Biphenyl and bimesityl tetrasulfonic acid - new linker molecules for coordination polymers
}

\author{
Florian Behler, Mathias S. Wickleder, and Jens Christoffers* \\ Institut für Chemie, Carl von Ossietzky Universität Oldenburg, 26111 Oldenburg, Germany \\ E-mail: jens.christoffers@uni-oldenburg.de
}

\begin{abstract}
Dedicated to Professor Jürgen Martens in honor of his outstanding contributions to synthetic organic chemistry
\end{abstract}

DOI: http://dx.doi.org/10.3998/ark.5550190.p008.911

\begin{abstract}
Biphenyl $\left(\mathrm{H}_{4} \mathrm{BPTS}\right)$ and bimesityl ( $\left.\mathrm{H}_{4} \mathrm{BMTS}\right)$ 3,3',5,5'-tetrasulfonic acids were prepared by Ullmann type coupling reactions of respective cuprates. The four sulfo groups were installed by nucleophilic displacement at respective tetrabromo biaryl derivatives with sodium isopropyl thiolate. The resulting thioether moieties were cleaved and subsequently oxidized to furnish the title compounds. The new acids $\mathrm{H}_{4}$ BPTS and $\mathrm{H}_{4}$ BMTS were used for the preparation of their respective copper salts which allowed for the detailed structural inspection of the tetrasulfonate anions by X-ray methods.
\end{abstract}

Keywords: Biaryls, cuprates, aromatic substitution, sulfonic acids, Ullmann coupling, oxidation

\section{Introduction}

The structural chemistry of coordination polymers (CPs) is stamped by the connection of cationic knots, i.e. metal ions or metal-oxo clusters, by anionic polydentate linkers. ${ }^{1-3}$ Depending on the nature of the linker the connection may occur in one, two or three dimensions. The compounds with three-dimensional linkage often show high porosity and are then called metal organic frameworks (MOFs). Due to their outstanding properties these compounds have been investigated in great detail. ${ }^{4-12}$ In most cases CPs and MOFs have been prepared using oligocarboxylic acids as linker molecules. As an example of a tetracarboxylic acid, pyromellitic acid (1, Figure 1) had been utilized as a linker with $D_{2 \mathrm{~h}}$ symmetry, e.g. for the preparation of a material called MIL-121. ${ }^{13}$ An constitutionally extended example of a compound with this symmetry is 3,3',5,5'-biphenyltetracarboxylic acid (3), where both phenyl rings are coplanar. Its copper salt was reported as so-called MOF-505. ${ }^{14}$ Introduction of four ortho-methyl groups 
would lead to $C_{2 \mathrm{v}}$ symmetry of the linker, because the two aromatic rings are now perpendicular to each other. A reasonable example would be so far unknown compound $\mathbf{5}$.<smiles>O=C(O)c1cc(C(=O)O)c(C(=O)O)cc1C(=O)O</smiles><smiles>O=C(O)c1cc(C(=O)O)cc(-c2cc(C(=O)O)cc(C(=O)O)c2)c1</smiles><smiles>Cc1c(C(=O)O)c(C)c(-c2c(C)c(C(=O)O)c(C)c(C(=O)O)c2C)c(C)c1C(=O)O</smiles>

5<smiles>O=S(=O)(O)c1cc(S(=O)(=O)O)c(S(=O)(=O)O)cc1S(=O)(=O)O</smiles><smiles>O=S(=O)(O)c1cc(-c2cc(S(=O)(=O)O)cc(S(=O)(=O)O)c2)cc(S(=O)(=O)O)c1</smiles>

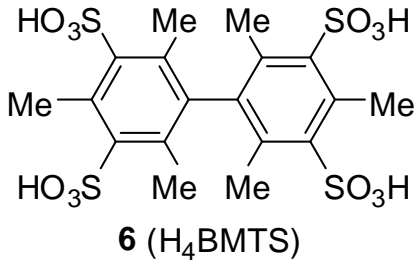

Figure 1. Aromatic tetracarboxylic and tetrasulfonic acids $\mathrm{H}_{4} \mathrm{BPTS}(4)$ and $\mathrm{H}_{4} \mathrm{BMTS}(\mathbf{6})$.

In order to extend the structural diversity of coordination polymers, we have initiated a research program on the preparation of new di- and oligosulfonic acids, ${ }^{15-19}$ which possess promising and advantageous properties when compared to carboxylic acids, for example, stronger acidity and enhanced thermal stability. In this course we had already reported on the use of benzene tetrasulfonic acid $\mathbf{2}$; in the solid state, its copper(II) salt formed ladder shaped chains. ${ }^{20}$ We now wish to extend this structural motif by preparation of biphenyl tetrasulfonic acid $4\left(\mathrm{H}_{4} \mathrm{BPTS}\right)$ with $D_{2 \mathrm{~h}}$ symmetry and the respective tilted bimesityl congener $\mathrm{H}_{4} \mathrm{BMTS}(6)$ $\left(C_{2 \mathrm{v}}\right)$.

\section{Results and Discussion}

The synthesis of $D_{2 \mathrm{~h}}$-symmetric tetrasulfonic acid $\mathbf{4}$ used tetrabromobiphenyl $\mathbf{8}$ as starting material, which was actually reported before in the literature; ${ }^{21,22}$ we however failed to reproduce the procedures used therein. Nevertheless, we could access compound $\mathbf{8}$ from tribromobenzene $\mathbf{7}$ via its Lipshutz cuprate ${ }^{23}$ (as reported for the respective bimesityl, ${ }^{24}$ see below), but we used nitrobenzene as oxidizing reagent ${ }^{25}$ instead of benzoquinone. We then proceeded with the formation of tetrathiol 9 as developed before in our laboratories: nucleophilic displacement of bromine by isopropyl thioether functions was followed by reductive cleavage of isopropyl groups. Compound $\mathbf{9}$ was then oxidized by hydrogen peroxide to yield the tetrasulfonic acid $\mathbf{4}$ as its tetrahydrate $\left(\mathrm{H}_{4} \mathrm{BPTS} \cdot 4 \mathrm{H}_{2} \mathrm{O}\right)$. 

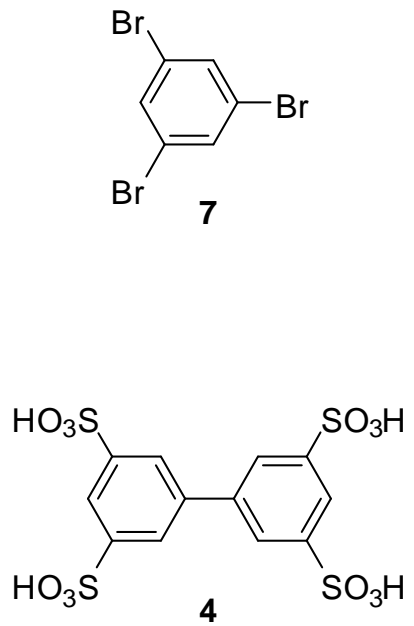
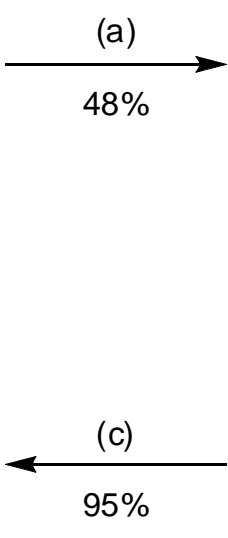
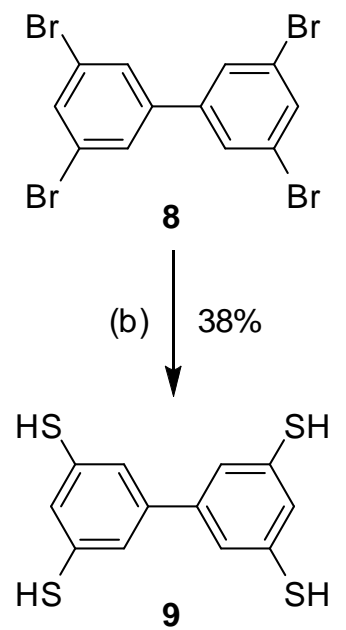

Reagents and conditions: (a) 1. 1.0 equiv. $n \mathrm{BuLi}, \mathrm{Et}_{2} \mathrm{O},-78{ }^{\circ} \mathrm{C}, 10 \mathrm{~min}$; 2.0 .5 equiv. $\mathrm{CuCN}$, $-60{ }^{\circ} \mathrm{C}, 1.5 \mathrm{~h}$; 3.1 .5 equiv. $\mathrm{PhNO}_{2}, 23{ }^{\circ} \mathrm{C}, 16 \mathrm{~h}$; (b) 10 equiv. $i \mathrm{PrSNa}, \mathrm{DMA}, 100{ }^{\circ} \mathrm{C}, 20 \mathrm{~h} ; 2.15$ equiv. $\mathrm{Na}, 100{ }^{\circ} \mathrm{C}, 6 \mathrm{~h}$; (c) 1.20 equiv. $\mathrm{H}_{2} \mathrm{O}_{2}$ (30\% in $\mathrm{H}_{2} \mathrm{O}$ ), $\mathrm{CHCl}_{3}, \mathrm{MeOH}, 23{ }^{\circ} \mathrm{C}, 20 \mathrm{~h} ; 2$. repeat step 1 , but only with water as solvent.

Scheme 1. Preparation of tetrasulfonic acid $\mathrm{H}_{4} \mathrm{BPTS}$ (4) in three steps from tribromobenzene 7.

For the synthesis of tetrasulfonic acid $\mathbf{6}$ we first tried the homocoupling of tribromomesitylene, but we failed. Therefore, we first prepared literature known bimesitylene ${ }^{26,27}$ $\mathbf{1 1}$ from iodomesitylene ${ }^{28} \mathbf{1 0}$ by the above approved protocol. The subsequent tetrabromination proceeded straightforward. Nucleophilic displacement of compound 13 with $i \mathrm{PrSNa}$ followed by reductive cleavage with sodium could not be performed in a sequential one flask protocol. We therefore isolated the tetrathioether $\mathbf{1 2}$ and degraded the isopropyl groups oxidatively with in situ formed chlorine furnishing the tetrasulfonylchloride 14. Hydrolysis of the latter material with hot water gave the final product 6 again as the tetrahydrate $\left(\mathrm{H}_{4} \mathrm{BMTS} \cdot 4 \mathrm{H}_{2} \mathrm{O}\right)$.

The molecular structure of both tetrasulfonic acids $\mathrm{H}_{4}$ BPTS (4) and $\mathrm{H}_{4} \mathrm{BMTS}$ (6) was established by X-ray crystallography of their respective copper(II) salts, which were obtained from neutralization of aqueous solutions of the respective acids with malachite followed by slow evaporation.

In the monoclinic structure of the biphenyl tetrasulfonate $\left\{\left[\mathrm{Cu}\left(\mathrm{H}_{2} \mathrm{O}\right)_{5}\right]_{2}(\mathrm{BPTS})\right\} \cdot 2 \mathrm{H}_{2} \mathrm{O} \mathbf{1 5}$ two of the $\left[\mathrm{SO}_{3}\right]$ groups are coordinated by $\mathrm{Cu}^{2+}$ ions both being in anti-conformation at the planar biphenyl backbone (Figure 2). The copper ions do not connect to further sulfonate groups and their coordination sphere is completed by five $\mathrm{H}_{2} \mathrm{O}$ molecules. The $\left[\mathrm{CuO}_{6}\right]$ octahedron shows a typical Jahn-Teller distortion and the elongated distances are those to the sulfonate ligand $\left(2.33 \AA\right.$ ) and to the $\mathrm{H}_{2} \mathrm{O}$ molecule with trans orientation to the $\left[\mathrm{SO}_{3}\right]$ moiety $(2.41 \AA)$. The molecular $\left.\left\{\left[\mathrm{Cu}\left(\mathrm{H}_{2} \mathrm{O}\right)_{5}\right]_{2}(\mathrm{BPTS})\right]\right\}$ complexes are connected by several hydrogen bonds, 
involving also two molecules of crystal water, which are associated to each of the noncoordinating $\left[\mathrm{SO}_{3}\right]$ moieties.

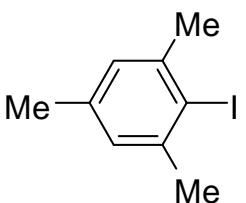

10

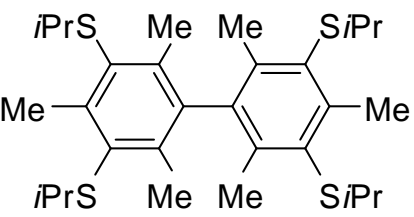

12

(d) $\ 91 \%$ (a)

$74 \%$
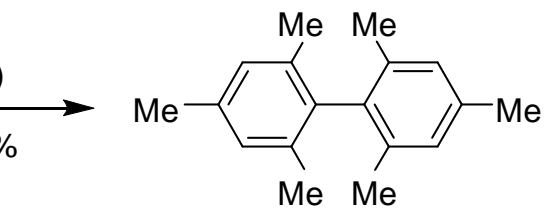

11

(b) $89 \%$

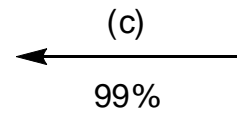

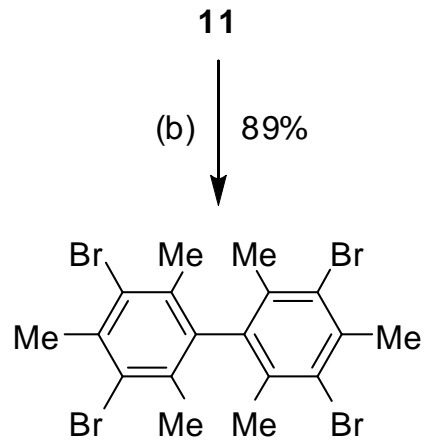

13

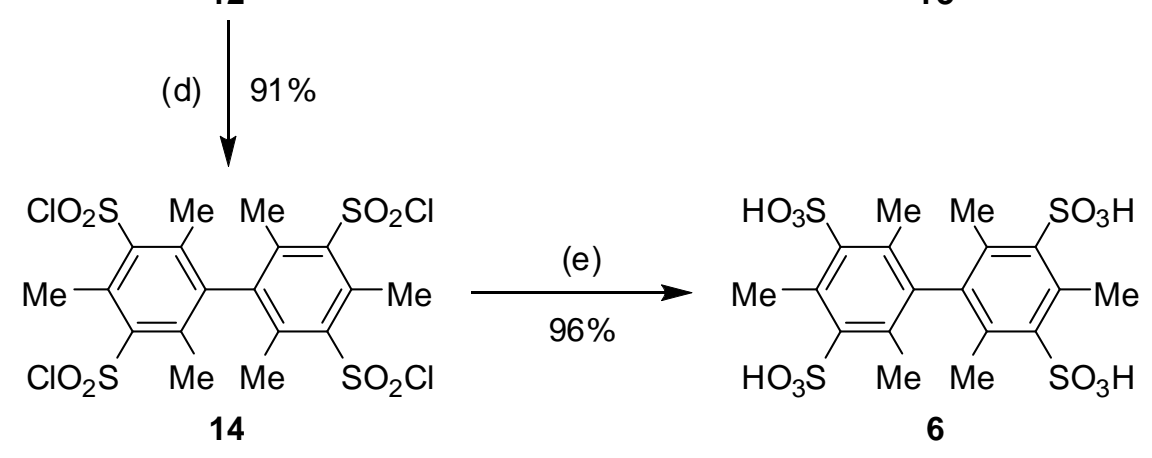

Reagents and conditions: (a) 1.2 .5 equiv. $t \mathrm{BuLi}, \mathrm{Et}_{2} \mathrm{O},-78{ }^{\circ} \mathrm{C}, 30 \mathrm{~min}$; 2.0 .5 equiv. $\mathrm{CuCN},-60$ ${ }^{\circ} \mathrm{C}, 2 \mathrm{~h} ; 3.1 .5$ equiv. $\mathrm{PhNO}_{2}, 23{ }^{\circ} \mathrm{C}, 16 \mathrm{~h}$; (b) 5.5 equiv. $\mathrm{Br}_{2}, 0.3$ equiv. $\mathrm{Fe}, \mathrm{CHCl}_{3}, 23{ }^{\circ} \mathrm{C}, 16 \mathrm{~h}$; (c) 16 equiv. $i \operatorname{PrSNa}$, DMA, $100{ }^{\circ} \mathrm{C}, 20 \mathrm{~h}$; (d) 16 equiv. $\mathrm{NCS}, 4.7$ equiv. $\mathrm{HCl}, \mathrm{H}_{2} \mathrm{O}, \mathrm{MeCN}, 0{ }^{\circ} \mathrm{C}$, 20 min; (e) $\mathrm{H}_{2} \mathrm{O}$, THF, $100^{\circ} \mathrm{C}, 1 \mathrm{~d}$.

Scheme 2. Preparation of tetrasulfonic acid $\mathrm{H}_{4} \mathrm{BMTS}(\mathbf{6})$ in five steps from iodomesitylene 10.

In the tetragonal structure of the copper(II) bimesitylene tetrasulfonate $\left\{\left[\mathrm{Cu}\left(\mathrm{H}_{2} \mathrm{O}\right)_{6}\right]_{2}(\mathrm{BMTS})\right\} \mathbf{1 6}$ two complex $\left[\mathrm{Cu}\left(\mathrm{H}_{2} \mathrm{O}\right)_{6}\right]^{2+}$ cations have no coordinating contact to the tetraanion $[\mathrm{BMTS}]^{4-}$. The octahedral complexes show a small Jahn-Teller distortion with distances of 2.028 and $2.151 \AA$, respectively. In Figure 3, only one of two symmetry-equivalent cations is depicted. The tetrasulfonate anion $[\mathrm{BMTS}]^{4-}$ shows the two planes of the aromatic rings in perpendicular conformation, as is enforced by the tetra-ortho methyl-substitution. In the crystal structure the complex $\left[\mathrm{Cu}\left(\mathrm{H}_{2} \mathrm{O}\right)_{6}\right]^{2+}$ cations and the $[\mathrm{BMTS}]^{4-}$ ions are alternatingly stacked in the [110] direction of the unit cell. Judged from the observed $\mathrm{O}-\mathrm{O}$ distances the 
formation of hydrogen bonds between the $\mathrm{H}_{2} \mathrm{O}$ molecules of the cations and the oxygen atoms of the $\left[\mathrm{SO}_{3}\right]$ groups of the anions can be assumed.

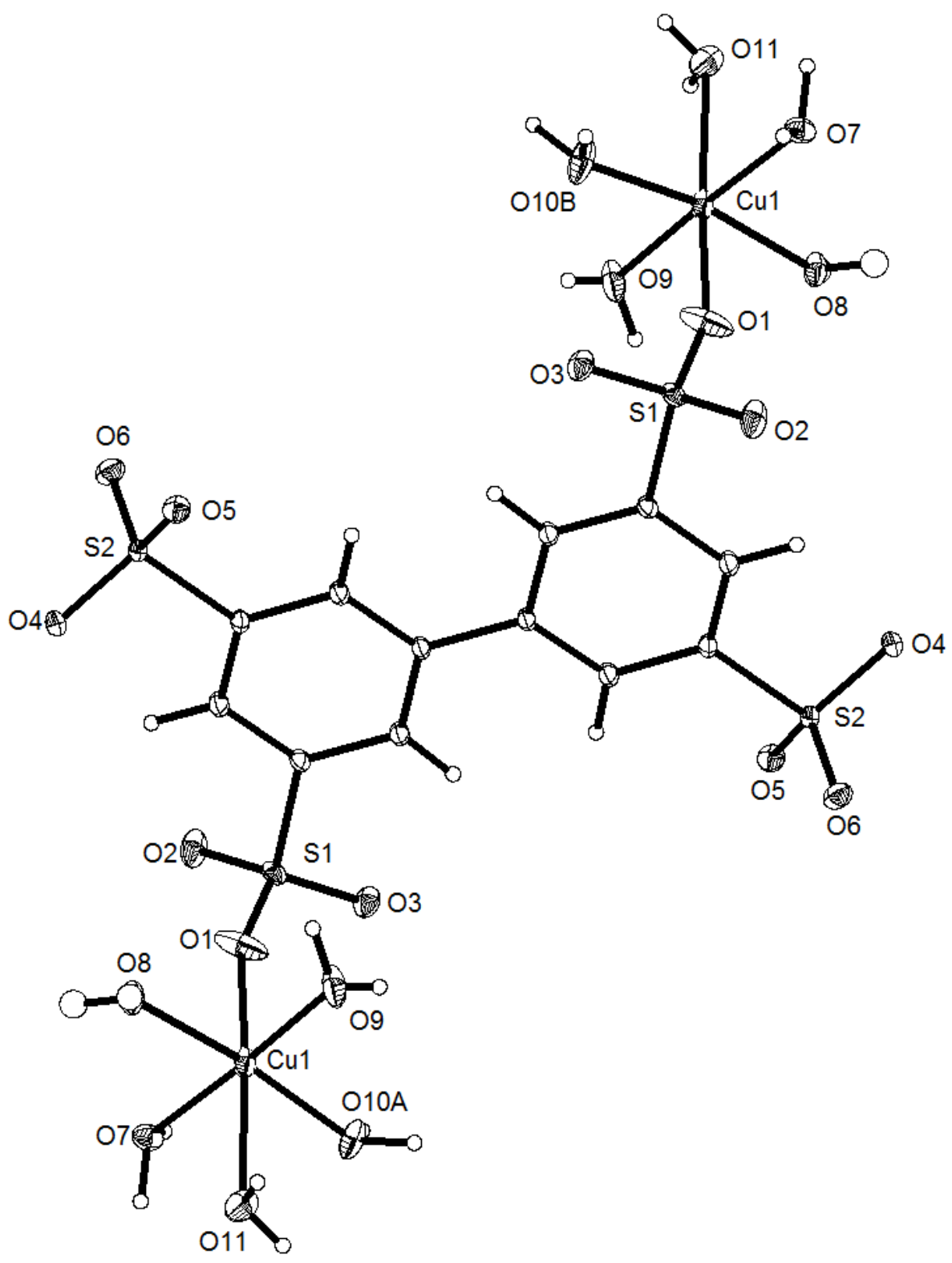

Figure 2. $\left.\left\{\left[\mathrm{Cu}\left(\mathrm{H}_{2} \mathrm{O}\right)_{5}\right]_{2}(\mathrm{BPTS})\right]\right\}$ molecule in the crystal structure of the copper(II) salt $\mathbf{1 5}$ of the tetrasulfonic acid $\mathrm{H}_{4}$ BPTS (4). Thermal ellipsoids are shown at a 50\% probability level. 


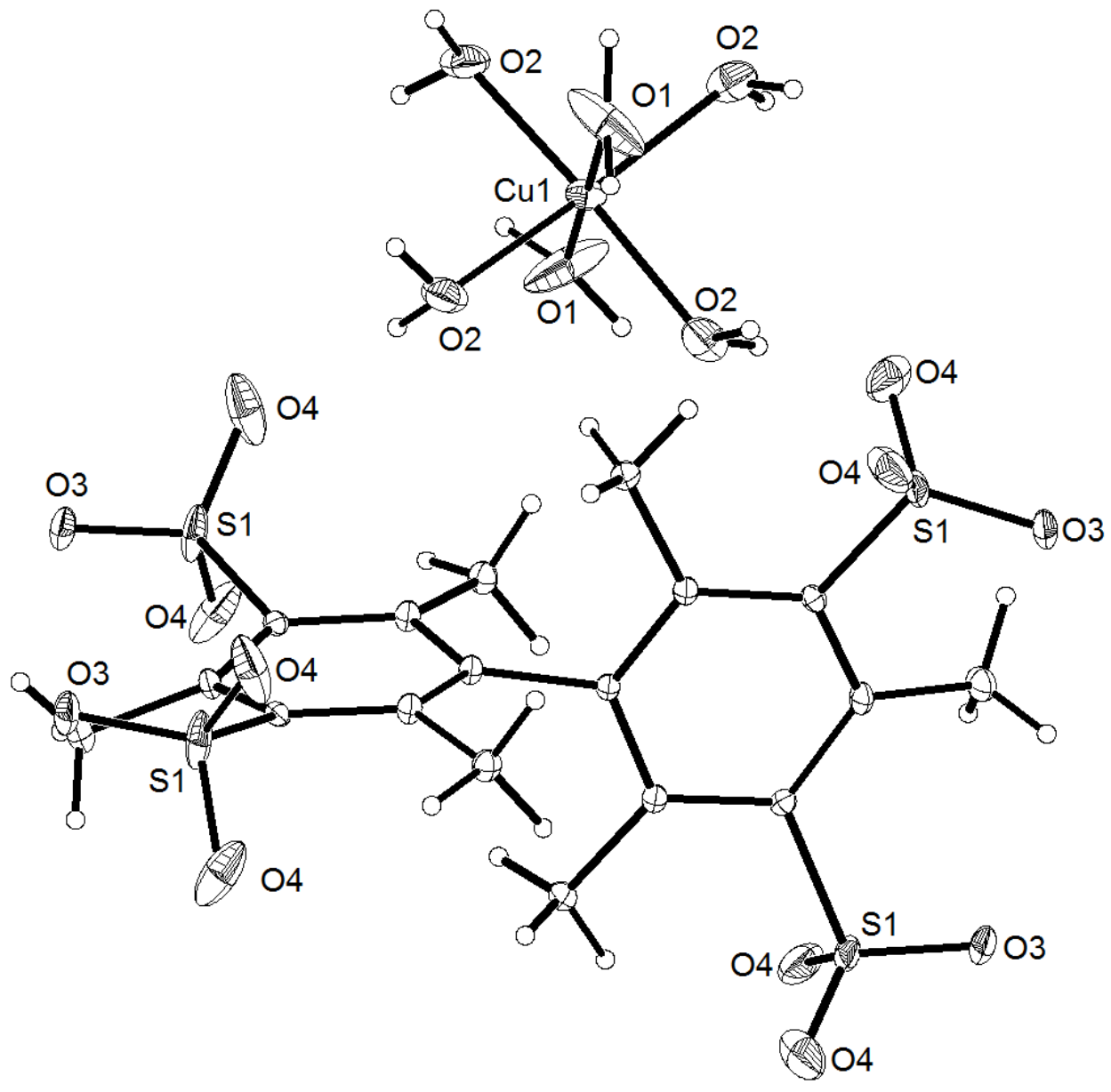

Figure 3. Tetrasulfonate anion $[\mathrm{BMTS}]^{4-}$ and complex $\left[\mathrm{Cu}\left(\mathrm{H}_{2} \mathrm{O}\right)_{6}\right]^{2+}$ in the crystal structure of the copper salt $\left\{\left[\mathrm{Cu}\left(\mathrm{H}_{2} \mathrm{O}\right)_{6}\right]_{2}\right.$ (BMTS) $\} \mathbf{1 6}$ of tetrasulfonic acid $\mathrm{H}_{4}$ BMTS (6) in the solid state. Thermal ellipsoids are shown at a $50 \%$ probability level.

\section{Conclusions}

Two new aromatic tetrasulfonic acids with a biphenyl and bimesityl backbone, $\mathrm{H}_{4}$ BPTS (4) and $\mathrm{H}_{4}$ BMTS (6), were prepared from tetrabromobiphenyl $\mathbf{8}$ and -bimesityl $\mathbf{1 3}$ in two or three steps, respectively. The key transformations were Ullman-type coupling reaction to achieve the biaryl motif, nucleophilic displacement reactions with sulfur nucleophiles and oxidation to achieve the four sulfo-residues. X-ray crystallographic structure analyses of the copper salts $\left.\left\{\left[\mathrm{Cu}\left(\mathrm{H}_{2} \mathrm{O}\right)_{5}\right]_{2}(\mathrm{BPTS})\right]\right\} 15$ and $\left\{\left[\mathrm{Cu}\left(\mathrm{H}_{2} \mathrm{O}\right)_{6}\right]_{2}(\mathrm{BMTS})\right\} \mathbf{1 6}$ revealed the planar $\left(D_{2 \mathrm{~h}}\right)$ and tilted $\left(C_{2 \mathrm{v}}\right)$ symmetries of the two biaryl backbones. Both tetrasulfonic acids will now be applied in our group as linker molecules for the preparation of coordination polymers and metal organic frameworks. 


\section{Experimental Section}

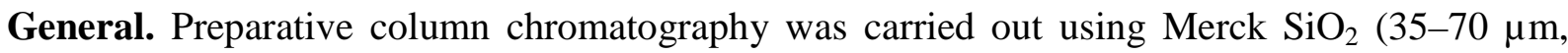
type $60 \mathrm{~A}$ ) with $n$-hexane, tert-butyl methyl ether (MTBE), and $\mathrm{CH}_{2} \mathrm{Cl}_{2}$ as eluents. TLC was performed on Merck aluminium plates coated with $\mathrm{SiO}_{2} \mathrm{~F}_{254} \cdot{ }^{1} \mathrm{H}$ and ${ }^{13} \mathrm{C}$ NMR spectra were recorded on Bruker Avance ARX 300 and DRX 500 instruments at $23{ }^{\circ} \mathrm{C}$ in $\mathrm{CDCl}_{3}$ or $\mathrm{D}_{2} \mathrm{O}$. Multiplicities of carbon signals were determined with DEPT experiments. MS and HRMS spectra were obtained with a Finnigan MAT95 (EI) and a Waters Q-TOF Premier (ESI) spectrometer. IR spectra were recorded on a Bruker Tensor 27 spectrometer equipped with a "GoldenGate" diamond ATR unit. Elemental analyses were measured with a Euro EA-CHNS instrument from HEKAtech. The X-ray single crystal investigations were performed with CCD diffractometer ( $\kappa$ APEX II, Bruker, Karlsruhe, Germany). Suitable crystals were mounted onto a glass needle ( $0.1 \mathrm{~mm})$ and placed into a stream of cold $\mathrm{N}_{2}\left(-153{ }^{\circ} \mathrm{C}\right)$ inside the diffractometer. An absorption correction was applied to the data using the program SADABS-2012/1..$^{29,30}$

3,3',5,5'-Tetrabromobiphenyl (8). $n$-Butyllithium ( $2.5 \mathrm{~mL}$ of a $2.5 \mathrm{~mol} / \mathrm{l}$ solution in $n$-hexane, $6.3 \mathrm{mmol}$ ) was added to a solution of 1,3,5-tribromobenzene (7) (2.00 g, $6.35 \mathrm{mmol})$ in $\mathrm{Et}_{2} \mathrm{O}$ (40 $\mathrm{mL})$ at $-78{ }^{\circ} \mathrm{C}$ under inert atmosphere. After $10 \mathrm{~min}, \mathrm{CuCN}(282 \mathrm{mg}, 3.18 \mathrm{mmol})$ was added and the reaction mixture was allowed to warm up to $-60{ }^{\circ} \mathrm{C}$ within $90 \mathrm{~min}$. Nitrobenzene $(0.98 \mathrm{~mL}$, $9.53 \mathrm{mmol}$ ) was then added in one portion and the dark solution stirred while warming to ambient temperature $(16 \mathrm{~h})$. An aqueous solution of $\mathrm{NH}_{3}(12.5 \% \mathrm{w} / \mathrm{w}, 80 \mathrm{~mL})$ was slowly added and the resulting mixture was extracted with MTBE $(3 \times 50 \mathrm{~mL})$. The combined organic layers were washed with water $(50 \mathrm{~mL})$ and brine $(50 \mathrm{~mL})$, dried over $\mathrm{MgSO}_{4}$, filtered and the solvent was removed in vacuum. Further purification was accomplished by column chromatography $\left(\mathrm{SiO}_{2}, n\right.$-hexane, $\left.\mathrm{R}_{\mathrm{f}} 0.69\right)$. The resulting material was washed with acetone $(20 \mathrm{~mL})$ to give the product 8 as a colorless solid ( $722 \mathrm{mg}, 1.54 \mathrm{mmol}, 48 \%)$, mp $190{ }^{\circ} \mathrm{C}\left(\right.$ ref. $\left.^{22} 190-191{ }^{\circ} \mathrm{C}\right) .{ }^{1} \mathrm{H}$ NMR $\left(500 \mathrm{MHz}, \mathrm{CDCl}_{3}\right): \delta 7.70(\mathrm{t}, J 1.7 \mathrm{~Hz}, 2 \mathrm{H}), 7.59(\mathrm{~d}, J 1.7 \mathrm{~Hz}, 4 \mathrm{H}) \mathrm{ppm} .{ }^{13} \mathrm{C}\left\{{ }^{1} \mathrm{H}\right\} \mathrm{NMR}$ $\left(126 \mathrm{MHz}, \mathrm{CDCl}_{3}\right): \delta 141.8(2 \mathrm{C}), 133.9(2 \mathrm{CH}), 129.0(4 \mathrm{CH}), 123.6$ (4 C) ppm. IR (ATR): 3103 (w), 3068 (m), 1579 (m), 1541 (s), 1407 (m), 1387 (m), 1098 (m), 1068 (m), 847 (s), 752 (s), $672(\mathrm{~m}), 653(\mathrm{~m}) \mathrm{cm}^{-1}$. MS (EI, $\left.70 \mathrm{eV}\right), \mathrm{m} / z(\%): 466(95)\left[\mathrm{M}^{+}\right], 308$ (25), 150 (25), 84 (100). Anal. calcd. for $\mathrm{C}_{12} \mathrm{H}_{6} \mathrm{Br}_{4}$ (469.80): C 30.68, H 1.29; found C 30.68, H 1.30.

Biphenyl-3,3',5,5'-tetrathiol (9). Sodium 2-propanethiolate (2.76 g, $28.1 \mathrm{mmol})$ was added to a solution of compound $8(1.32 \mathrm{~g}, 2.81 \mathrm{mmol})$ in DMA $(15 \mathrm{~mL})$ under inert atmosphere and the resulting suspension was stirred at $100{ }^{\circ} \mathrm{C}$ for $20 \mathrm{~h}$. Sodium (969 mg, $42.1 \mathrm{mmol}$ ) was added at the same temperature and the reaction mixture was allowed to stir for $6 \mathrm{~h}$. The conversion was monitored by GC. In case of incomplete conversion, further sodium was added. After full conversion had been achieved, water $(10 \mathrm{~mL})$ was slowly and carefully added and the solution was acidified by conc. hydrochloric acid until $\mathrm{pH} 1$ (ca. $3 \mathrm{~mL})$. More water $(50 \mathrm{~mL})$ was added and the resulting suspension was extracted with $\operatorname{MTBE}(3 \times 50 \mathrm{~mL})$. The combined organic layers were washed with hydrochloric acid $(50 \mathrm{~mL}, 1 \mathrm{~mol} / \mathrm{l})$, water $(50 \mathrm{~mL})$ and brine $(50 \mathrm{~mL})$, 
dried over $\mathrm{MgSO}_{4}$ and filtered. After removal of the solvent in vacuum the residue was washed with hot methanol $(100 \mathrm{~mL})$ and the precipitate filtered off to yield the title compound 9 as a slightly yellow solid (466 mg, $1.65 \mathrm{mmol}, 59 \%)$, mp $130{ }^{\circ} \mathrm{C} .{ }^{1} \mathrm{H}$ NMR (500 MHz, $\mathrm{CDCl}_{3}$ ): $\delta$ $7.18(\mathrm{~s}, 6 \mathrm{H}), 3.50(\mathrm{~s}, 4 \mathrm{H}) \mathrm{ppm} .{ }^{13} \mathrm{C}\left\{{ }^{1} \mathrm{H}\right\} \mathrm{NMR}\left(126 \mathrm{MHz}, \mathrm{CDCl}_{3}\right): \delta 141.4(2 \mathrm{C}), 132.8(4 \mathrm{C})$, 128.7 (2 CH), 125.2 (4 CH) ppm. IR (ATR): 3047 (w), 2957 (m), 2927 (m), 2557 (m), 1573 (m), 1552 (s), 1404 (m), 1379 (m), 1127 (m), 840 (s), 795 (s), 681 (s) $\mathrm{cm}^{-1}$. MS (EI, $\left.70 \mathrm{eV}\right), \mathrm{m} / z$ (\%): 282 (100) $\left[\mathrm{M}^{+}\right], 248$ (8), 216 (23), 171 (10). HRMS (EI, $70 \mathrm{eV}$ ) calcd. for $\mathrm{C}_{12} \mathrm{H}_{10} \mathrm{~S}_{4}$ : 281.9665; found $281.9668\left[\mathrm{M}^{+}\right]$. Anal. calcd. for $\mathrm{C}_{12} \mathrm{H}_{10} \mathrm{~S}_{4}$ (282.45): C 51.03, H 3.57, S 45.40; found C 51.04, H 3.56, S 45.64 .

Biphenyl-3,3',5,5'-tetrasulfonic acid tetrahydrate, $\mathrm{H}_{4}$ PBTS $-4 \mathrm{H}_{2} \mathrm{O}$ (4). Hydrogen peroxide (30\% solution in $\mathrm{H}_{2} \mathrm{O}, 2.17 \mathrm{~mL}, 21.2 \mathrm{mmol}$ ) was added to a suspension of compound 9 (300 mg, $1.06 \mathrm{mmol})$ in $\mathrm{CHCl}_{3}(30 \mathrm{~mL})$ and $\mathrm{MeOH}(6 \mathrm{~mL})$. The reaction mixture was allowed to stir at room temperature for $20 \mathrm{~h}$. The volatiles were evaporated and the residue redissolved in water $(30 \mathrm{~mL})$ and treated again with hydrogen peroxide $\left(30 \%\right.$ solution in $\mathrm{H}_{2} \mathrm{O}, 2.17 \mathrm{~mL}, 21.2 \mathrm{mmol}$ ). After stirring for another $20 \mathrm{~h}$, all volatiles were removed in vacuum to yield the product 4 as a hygroscopic colorless solid (554 mg, $1.01 \mathrm{mmol}, 95 \%)$, decomp. $150-160{ }^{\circ} \mathrm{C} .{ }^{1} \mathrm{H}$ NMR (500 $\left.\mathrm{MHz}, \mathrm{D}_{2} \mathrm{O}\right): \delta 8.28(\mathrm{~s}, 4 \mathrm{H}), 8.24(\mathrm{~s}, 2 \mathrm{H}) \mathrm{ppm} .{ }^{13} \mathrm{C}\left\{{ }^{1} \mathrm{H}\right\} \mathrm{NMR}\left(126 \mathrm{MHz}, \mathrm{D}_{2} \mathrm{O}\right): \delta 144.32$ (4 C), 140.6 (2 C), 127.1 (4 CH), 122.5 (2 CH) ppm. IR (ATR): $3070(\mathrm{w}), 1668(\mathrm{~s}), 1110$ (m), 1013 (m), $682(\mathrm{~m}), 587(\mathrm{~m}) \mathrm{cm}^{-1}$. MS (ESI, neg.), m/z: $473\left[\mathrm{M}-\mathrm{H}^{+}\right], 236\left[\mathrm{M}-2 \mathrm{H}^{+}\right], 157\left[\mathrm{M}-3 \mathrm{H}^{+}\right]$. HRMS (ESI, neg.): calcd. for $\mathrm{C}_{12} \mathrm{H}_{8} \mathrm{O}_{12} \mathrm{~S}_{4}{ }^{2-}$ : 235.9455; found $235.9450\left[\mathrm{M}-2 \mathrm{H}^{+}\right]$. Anal. calcd. for $\mathrm{C}_{12} \mathrm{H}_{10} \mathrm{O}_{12} \mathrm{~S}_{4} \cdot 4 \mathrm{H}_{2} \mathrm{O}$ (546.50): C 26.37, H 3.32, S 23.47; found C 26.37, H 3.33, S 23.45.

Bimesitylene (11). tert-Butyllithium $(9.0 \mathrm{~mL}$ of a $1.7 \mathrm{~mol} / 1$ solution in $n$-pentane, $15.3 \mathrm{mmol})$ was added to iodomesitylene $(\mathbf{1 0})(1.51 \mathrm{~g}, 6.14 \mathrm{mmol})$ in $\mathrm{Et}_{2} \mathrm{O}(20 \mathrm{~mL})$ at $-78{ }^{\circ} \mathrm{C}$ under inert atmosphere. After $30 \mathrm{~min}, \mathrm{CuCN}(273 \mathrm{mg}, 3.07 \mathrm{mmol})$ was added and the suspension stirred at $-60{ }^{\circ} \mathrm{C}$ for $2 \mathrm{~h}$. The reaction mixture was then treated with nitrobenzene $(0.94 \mathrm{~mL}, 9.12 \mathrm{mmol})$ and allowed to warm up to room temperature overnight. An aqueous solution of $\mathrm{NH}_{3}(12.5 \%$ w/w, $80 \mathrm{~mL})$ was slowly added and the resulting residue was extracted with MTBE $(3 \mathrm{x} 50 \mathrm{~mL})$. The combined organic layers were washed with water $(50 \mathrm{~mL})$ and brine $(50 \mathrm{~mL})$, dried over $\mathrm{MgSO}_{4}$, filtered, and the solvent was removed in vacuum. The product 11 could be obtained after column chromatography $\left(\mathrm{SiO}_{2}, n\right.$-hexane, $\mathrm{R}_{\mathrm{f}} 0.43$ ) as a colorless solid (542 $\mathrm{mg}, 2.27 \mathrm{mmol}$, 74\%), mp $98{ }^{\circ} \mathrm{C}$ (ref. ${ }^{27} 99-100{ }^{\circ} \mathrm{C}$ ). ${ }^{1} \mathrm{H}$ NMR (300 MHz, $\left.\mathrm{CDCl}_{3}\right): \delta 6.94$ (s, $\left.4 \mathrm{H}\right), 2.34$ (s, $6 \mathrm{H}$ ), $1.87(\mathrm{~s}, 12 \mathrm{H}) \mathrm{ppm} .{ }^{13} \mathrm{C}\left\{{ }^{1} \mathrm{H}\right\} \mathrm{NMR}\left(75 \mathrm{MHz}, \mathrm{CDCl}_{3}\right): \delta 137.0(2 \mathrm{C}), 136.0(2 \mathrm{C}), 135.5(4 \mathrm{C})$, $128.2(4 \mathrm{CH}), 21.1\left(2 \mathrm{CH}_{3}\right), 19.8\left(4 \mathrm{CH}_{3}\right)$ ppm. IR (ATR): $2997(\mathrm{w}), 2938(\mathrm{~m}), 2916(\mathrm{~m}), 1470$ (m), 1436 (m), 1375 (m), 1004 (m), 852 (s), 595 (m) cm ${ }^{-1}$. MS (EI, $\left.70 \mathrm{eV}\right), \mathrm{m} / \mathrm{z}$ (\%): 238 (99) $\left[\mathrm{M}^{+}\right], 223$ (100), 208 (33), 193 (25). Anal. calcd. for $\mathrm{C}_{18} \mathrm{H}_{22}$ (238.37): C 90.70, H 9.30; found C 90.73, H 9.34 .

3,3',5,5'-Tetrabromobimesitylene (13). A solution of bromine $(0.2 \mathrm{~mL}, 3.2 \mathrm{mmol})$ in $\mathrm{CHCl}_{3}$ $(2.9 \mathrm{~mL})$ was added to a suspension of bimesitylene (11) $(140 \mathrm{mg}, 587 \mu \mathrm{mol})$ and iron $(9.8 \mathrm{mg}$, $176 \mu \mathrm{mol})$ in $\mathrm{CHCl}_{3}(3.0 \mathrm{~mL})$ at ambient temperature. The reaction mixture was allowed to stir for $16 \mathrm{~h}$. Water $(20 \mathrm{~mL})$ was then added and the aqueous layer was extracted with $\mathrm{CH}_{2} \mathrm{Cl}_{2}(3 \mathrm{x}$ 
$20 \mathrm{~mL}$ ). The combined organic layers were washed with a saturated solution of $\mathrm{Na}_{2} \mathrm{~S}_{2} \mathrm{O}_{3}(20 \mathrm{~mL})$ and water $(20 \mathrm{~mL})$, dried over $\mathrm{MgSO}_{4}$, filtered and the solvent was removed in vacuum. The crude product could be purified by washing with hot acetone $(10 \mathrm{~mL})$ to yield the title compound 13 as a colorless solid $(290 \mathrm{mg}, 524 \mu \mathrm{mol}, 89 \%)$, mp $236{ }^{\circ} \mathrm{C} .{ }^{1} \mathrm{H}$ NMR $\left(500 \mathrm{MHz}, \mathrm{CDCl}_{3}\right): \delta$ 2.74 (s, $6 \mathrm{H}), 1.98$ (s, $12 \mathrm{H}) \mathrm{ppm} .{ }^{13} \mathrm{C}\left\{{ }^{1} \mathrm{H}\right\} \mathrm{NMR}\left(126 \mathrm{MHz}, \mathrm{CDCl}_{3}\right): \delta 139.9(2 \mathrm{C}), 137.2(2 \mathrm{C})$, 134.9 (4 C), 126.2 (4 C), 25.9 (2 $\left.\mathrm{CH}_{3}\right), 21.5\left(4 \mathrm{CH}_{3}\right)$ ppm. IR (ATR): 2996 (w), 2945 (m), 2917 (m), 1440 (m), 1364 (s), 1047 (m), 1023 (m), 958 (vs), 944 (s), 663 (s), 626 (m) cm ${ }^{-1}$. MS (EI,

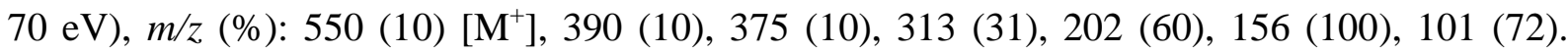
Anal. calcd. for $\mathrm{C}_{18} \mathrm{H}_{18} \mathrm{Br}_{4}$ (553.96): C 39.03, H 3.28; found C 39.06, H 3.28.

3,3',5,5'-Tetrakis(isopropylthio)bimesitylene (12). Sodium isopropylthiolate (1.47 g, 15.0 mmol) was added to a solution of compound $13(519 \mathrm{mg}, 937 \mu \mathrm{mol})$ in DMA $(15 \mathrm{~mL})$ under inert atmosphere. The mixture was stirred at $100{ }^{\circ} \mathrm{C}$ for $20 \mathrm{~h}$. After cooling to ambient temperature, water $(80 \mathrm{~mL})$ was added and the resulting suspension was extracted with $n$-hexane (3 x $50 \mathrm{~mL}$ ). The combined organic extracts were washed with brine $(50 \mathrm{~mL})$, dried over $\mathrm{MgSO}_{4}$, filtered and the solvent was removed in vacuum. The residue was purified by column chromatography $\left(\mathrm{SiO}_{2}, n\right.$-hexane/MTBE $10: 1, \mathrm{R}_{\mathrm{f}}$ 0.81) to yield the title compound 12 as a colorless solid (500 mg, $935 \mu \mathrm{mol}, 99 \%), \mathrm{mp} 126{ }^{\circ} \mathrm{C}$. ${ }^{1} \mathrm{H} \mathrm{NMR}\left(500 \mathrm{MHz}, \mathrm{CDCl}_{3}\right.$ ): $\delta 3.09$ (hept, $J 6.6 \mathrm{~Hz}, 4 \mathrm{H}), 2.93(\mathrm{~s}, 6 \mathrm{H}), 2.09(\mathrm{~s}, 12 \mathrm{H}), 1.19(\mathrm{~d}, J 6.6 \mathrm{~Hz}, 24 \mathrm{H}) \mathrm{ppm} .{ }^{13} \mathrm{C}\left\{{ }^{1} \mathrm{H}\right\} \mathrm{NMR}(126$ $\mathrm{MHz}, \mathrm{CDCl}_{3}$ ): $\delta 147.1$ (2 C), 140.9 (4 C), 140.3 (2 C), 132.9 (4 C), $39.1(4 \mathrm{CH}), 23.0\left(8 \mathrm{CH}_{3}\right)$, $22.5\left(2 \mathrm{CH}_{3}\right), 19.8\left(4 \mathrm{CH}_{3}\right)$ ppm. IR (ATR): 2960 (s), 2922 (m), 2862 (m), 1441 (vs), 1375 (s), 1362 (m), 1243 (s), 1151 (m), 1052 (s), 1007 (m), 972 (m), 935 (m) cm ${ }^{-1}$. MS (ESI, pos.), m/z: $557\left[\mathrm{M}+\mathrm{Na}^{+}\right], 535\left[\mathrm{M}+\mathrm{H}^{+}\right]$. Anal. calcd. for $\mathrm{C}_{30} \mathrm{H}_{46} \mathrm{~S}_{4}$ (534.95): C 67.36, H 8.67, S 23.97; found C 67.37, H 8.66, S 23.98.

Bimesitylene-3,3',5,5'-tetrasulfonylchloride (14). $N$-Chlorosuccinimide (1.98 g, $14.8 \mathrm{mmol})$ was added portionwise to a suspension of compound 13 (496 mg, $927 \mu \mathrm{mol})$ in $\mathrm{MeCN}(11 \mathrm{~mL})$ and hydrochloric acid $(2.2 \mathrm{~mL}$ of a $2 \mathrm{~mol} / \mathrm{l}$ solution in water, $4.4 \mathrm{mmol})$ at $0{ }^{\circ} \mathrm{C}$. The reaction mixture stirred for $20 \mathrm{~min}$. Water $(20 \mathrm{~mL})$ was then added and the aqueous layer was extracted with $\mathrm{CH}_{2} \mathrm{Cl}_{2}(3 \times 10 \mathrm{~mL})$. The combined organic layers were dried over $\mathrm{MgSO}_{4}$, filtered and the solvent was removed in vacuum. After purification by column chromatography $\left(\mathrm{SiO}_{2}, \mathrm{CH}_{2} \mathrm{Cl}_{2}\right.$, $\mathrm{R}_{\mathrm{f}} 0.87$ ) the product 14 could be obtained as a colorless solid (532 mg, $841 \mu \mathrm{mol}, 91 \%$ ), decomp. $170{ }^{\circ} \mathrm{C} .{ }^{1} \mathrm{H}$ NMR $\left(500 \mathrm{MHz}, \mathrm{CDCl}_{3}\right): \delta 3.23(\mathrm{~s}, 6 \mathrm{H}), 2.39(\mathrm{~s}, 12 \mathrm{H}) \mathrm{ppm} .{ }^{13} \mathrm{C}\left\{{ }^{1} \mathrm{H}\right\} \mathrm{NMR}(126$ $\mathrm{MHz}, \mathrm{CDCl}_{3}$ ): $\delta 145.5$ (4 C), 143.9 (4 C), 143.3 (2 C), 141.2 (2 C), $22.0\left(2 \mathrm{CH}_{3}\right), 20.6\left(4 \mathrm{CH}_{3}\right)$ ppm. IR (ATR): 2937 (w), 1391 (m), 1370 (s), 1345 (m), 1171 (vs), 701 (s), 624 (m), 543 (s) cm

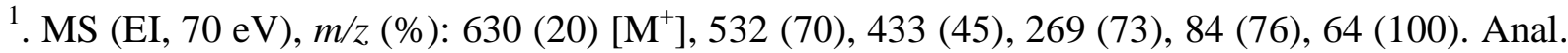
calcd. for $\mathrm{C}_{18} \mathrm{H}_{18} \mathrm{Cl}_{4} \mathrm{O}_{8} \mathrm{~S}_{4}$ (632.37): C 34.19, H 2.87, S 20.28; found C 34.24, H 2.87, S 20.31.

Bimesitylene-3,3',5,5'-tetrasulfonic acid tetrahydrate, $\mathrm{H}_{4} \mathrm{BMTS} \cdot 4 \mathrm{H}_{2} \mathrm{O}$ (6). A suspension of compound $14(136 \mathrm{mg}, 215 \mu \mathrm{mol})$ in water $(15 \mathrm{~mL})$ was refluxed for $16 \mathrm{~h}$. THF $(8 \mathrm{~mL})$ was then added and the solution stirred at reflux temperature for $6 \mathrm{~h}$. After cooling to ambient temperature the reaction mixture was filtered and the filtrate concentrated in vacuum to yield the title compound 6 as a colorless, strongly hygroscopic solid (130 mg, $206 \mu \mathrm{mol}, 96 \%) .{ }^{1} \mathrm{H}$ NMR (500 
$\left.\mathrm{MHz}, \mathrm{D}_{2} \mathrm{O}\right): \delta 2.76(\mathrm{~s}, 6 \mathrm{H}), 2.00(\mathrm{~s}, 12 \mathrm{H}) \mathrm{ppm} .{ }^{13} \mathrm{C}\left\{{ }^{1} \mathrm{H}\right\} \mathrm{NMR}\left(126 \mathrm{MHz}, \mathrm{D}_{2} \mathrm{O}\right): \delta 142.0(4 \mathrm{C})$, 141.3 (2 C), 137.6 (4 C), $136.6(2 \mathrm{C}), 21.3\left(2 \mathrm{CH}_{3}\right), 18.9\left(4 \mathrm{CH}_{3}\right)$ ppm. IR (ATR): 3367 (s br), 2937 (w), 1686 (m br), 1147 (s), 1109 (m), 1032 (s), 1017 (s), 671 (m), 526 (m) cm ${ }^{-1}$. MS (ESI, neg.), $m / z: 557\left[\mathrm{M}-\mathrm{H}^{+}\right], 278\left[\mathrm{M}-2 \mathrm{H}^{+}\right]$. HRMS (ESI, neg.): calcd. for $\mathrm{C}_{18} \mathrm{H}_{21} \mathrm{O}_{22} \mathrm{~S}_{4}{ }^{-}: 556.9916$; found $556.9898\left[\mathrm{M}-\mathrm{H}^{+}\right]$.

Bis[pentaquacopper(II)] biphenyl-3,3',5,5'-tetrasulfonate dihydrate, $\left[\mathrm{Cu}\left(\mathrm{OH}_{2}\right)_{5}\right](\mathrm{BPTS}) \cdot 2$ $\mathbf{H}_{2} \mathrm{O}$ (15). $\mathrm{Cu}_{2}(\mathrm{OH})_{2}\left(\mathrm{CO}_{3}\right)(33 \mathrm{mg}, 0.15 \mathrm{mmol})$ was added to a solution of tetrasulfonic acid 4 $(80 \mathrm{mg}, 147 \mu \mathrm{mol})$ in water $(10 \mathrm{~mL})$. The mixture was stirred at $50{ }^{\circ} \mathrm{C}$ for $20 \mathrm{~h}$. The resulting suspension was filtered and the solvent evaporated to yield the title compound $\mathbf{1 5}$ as a blue solid (95 mg, $117 \mu \mathrm{mol}, 79 \%$ ), which contained single crystals. ${ }^{1} \mathrm{H}$ NMR (500 MHz, $\mathrm{D}_{2} \mathrm{O}$ ): $\delta 8.35$ (br, $6 \mathrm{H})$ ppm. ${ }^{13} \mathrm{C}\left\{{ }^{1} \mathrm{H}\right\}$ NMR (126 MHz, $\mathrm{D}_{2} \mathrm{O}$ ): $\delta 144.5$ (4 C), 140.7 (2 C), 127.3 (4 CH), 122.7 (2 $\mathrm{CH})$ ppm. $\mathrm{C}_{12} \mathrm{H}_{6} \mathrm{Cu}_{2} \mathrm{O}_{12} \mathrm{~S}_{4} \cdot 12 \mathrm{H}_{2} \mathrm{O}$ (813.68). The monoclinic crystal structure $\left[P 2_{1} / c, Z 2, a\right.$ 5.8423(3), $b$ 11.2646(6), c 20.995(1) $\AA$, $\beta$ 97.501 ${ }^{\circ}$ ] was solved by direct methods and expanded using Fourier techniques. One of the water molecules in the structure was treated by a split model. The structure refinement using 6643 unique reflections led to residuals of R1 0.0275 and wR2 0.0720. CCDC-1013955 contains the supplementary crystallographic data for this compound. These data can be obtained free of charge via www.ccdc.cam.ac.uk, or by emailing data_request@ccdc.cam.ac.uk, or by contacting The Cambridge Crystallographic Data Centre, 12, Union Road, Cambridge CB2 1EZ, UK; fax: +44 1223336033.

Bis[hexaquacopper(II)] bimesitylene-3,3',5,5'-tetrasulfonate, [Cu(OH$\left.)_{6}\right](\mathrm{BMTS})$ (16). $\mathrm{Cu}_{2}(\mathrm{OH})_{2}\left(\mathrm{CO}_{3}\right)(93 \mathrm{mg}, 0.42 \mathrm{mmol})$ was added to a solution of tetrasulfonic acid $\mathbf{6}(265 \mathrm{mg}, 421$ $\mu \mathrm{mol})$ in water $(10 \mathrm{~mL})$. The mixture was stirred at $50{ }^{\circ} \mathrm{C}$ for $20 \mathrm{~h}$. The resulting suspension was filtered and the solvent evaporated to yield the title compound $\mathbf{1 6}$ as a blue solid (299 $\mathbf{m g}, 333$ $\mu$ mol, 79\%), which contained single crystals. $\mathrm{C}_{18} \mathrm{H}_{18} \mathrm{Cu}_{2} \mathrm{O}_{12} \mathrm{~S}_{4} \cdot 12 \mathrm{H}_{2} \mathrm{O}$ (897.84). The tetragonal crystal structure [I-42m, Z 2, a 11.2232(7), c 13.119(1) ^] was solved by direct methods and expanded using Fourier techniques. Three carbon atoms of the phenyl rings of the anion show a slight disorder which could be easily resolved using a split model. The structure refinement based on 2128 unique reflections led to residuals of R1 0.0341 and wR2 0.0835. CCDC-1013956 contains the supplementary crystallographic data for this compound. These data can be obtained free of charge via www.ccdc.cam.ac.uk, or by emailing data_request@ccdc.cam.ac.uk, or by contacting The Cambridge Crystallographic Data Centre, 12, Union Road, Cambridge CB2 1EZ, UK; fax: +44 1223336033.

Supplementary Material Available: ${ }^{1} \mathrm{H}$ and ${ }^{13} \mathrm{C}$ NMR spectra of all reported compounds. 


\section{Acknowledgements}

We are grateful to Marc Schmidtmann for X-ray crystallography. This work was generously funded by the Deutsche Forschungsgemeinschaft.

\section{References}

1. Janiak, C. Dalton Trans. 2003, 2781-2804. http://dx.doi.org/10.1039/b305705b

2. Cheetham, A. K.; Rao, C. N. R.; Feller, R. K. Chem. Commun. 2006, 4780-4795. http://dx.doi.org/10.1039/b610264f

3. Janiak, C.; Vieth, J. K. New J. Chem. 2010, 34, 2366-2388. http://dx.doi.org/10.1039/b610264f

4. Gascon, J.; Corma, A.; Kapteijn, F.; Llabres i Xamena, F. X. ACS Catal. 2014, 4, 361-378. http://dx.doi.org/10.1021/cs400959k

5. Herm, Z. R.; Bloch, E. D.; Long, J. R. Chem. Mater. 2014, 26, 323-338. http://dx.doi.org/10.1021/cm402897c

6. Dhakshinamoorthy, A.; Opanasenko, M.; Cejka, J.; Garcia, H. Catal. Sci. Technol. 2013, 3, 2509-2540.

http://dx.doi.org/10.1039/c3cy00350g

7. Li, S.-L.; Xu, Q. Energy Environ. Sci. 2013, 6, 1656-1683. http://dx.doi.org/10.1039/c3ee40507a

8. Yoon, M.; Suh, K.; Natarajan, S.; Kim, K. Angew. Chem. 2013, 125, 2752-2764; Angew. Chem. Int. Ed. 2013, 52, 2688-2700. http://dx.doi.org/10.1002/anie.201206410

9. Furukawa, H.; Cordova, K. E.; O'Keeffe, M.; Yaghi, O. M. Science 2013, 341, 1230444. http://dx.doi.org/10.1126/science.1230444

10. Cook, T. R.; Zheng, Y.-R.; Stang, P. J. Chem. Rev. 2013, 113, 734-777. http://dx.doi.org/10.1021/cr3002824

11. Lee, Y.-R.; Kim, J.; Ahn, W.-S. Korean J. Chem. Eng. 2013, 30, 1667-1680. http://dx.doi.org/10.1007/s11814-013-0140-6

12. Wang, C.; Liu, D.; Lin, W. J. Am. Chem. Soc. 2013, 135, 13222-13234. http://dx.doi.org/10.1021/ja308229p

13. Volkringer, C.; Loiseau, T.; Guillou, N.; Ferey, G.; Haouas, M.; Taulelle, F.; Elkaim, E.; Stock, N. Inorg. Chem. 2010, 49, 9852-9862. http://dx.doi.org/10.1021/ic101128w

14. Chen, B.; Ockwig, N. W.; Millward, A. R.; Contreras, D. S.; Yaghi, O. M. Angew. Chem. 2005, 117, 4823-4827; Angew. Chem. Int. Ed. 2005, 44, 4745-4749. http://dx.doi.org/10.1002/anie.200462787 
15. Mietrach, A.; Muesmann, T. W. T.; Christoffers, J.; Wickleder, M. S. Eur. J. Inorg. Chem. 2009, 5328-5334. http://dx.doi.org/10.1002/ejic.200900914

16. Muesmann, T. W. T.; Zitzer, C.; Mietrach, A.; Klüner, T.; Christoffers, J.; Wickleder, M. S. Dalton Trans. 2011, 40, 3128-3141.

http://dx.doi.org/10.1039/c0dt01223h

17. Muesmann, T. W. T.; Zitzer, C.; Wickleder, M. S.; Christoffers, J. Inorg. Chim. Acta 2011, $369,45-48$. http://dx.doi.org/10.1016/j.ica.2010.12.026

18. Mietrach, A.; Muesmann, T. W. T.; Zilinski, C.; Christoffers, J.; Wickleder, M. S. Z. Anorg. Allg. Chem. 2011, 637, 195-200.

19. Muesmann, T. W. T.; Wickleder, M. S.; Zitzer, C.; Christoffers, J. Synlett 2013, 24, 959-962. http://dx.doi.org/10.1055/s-0032-1317806

20. Muesmann, T. W. T.; Mietrach, A.; Christoffers, J.; Wickleder, M. S. Z. Anorg. Allg. Chem. 2010, 636, 1307-1312. http://dx.doi.org/10.1002/zaac.201000056

21. Su, S.-J.; Tanaka, D.; Li, Y.-J.; Sasabe, H.; Takeda, T.; Kido, J. Org. Lett. 2008, 10, 941944. http://dx.doi.org/10.1021/o17030872

22. Kirai, N.; Yamamoto, Y. Eur. J. Org. Chem. 2009, 1864-1867. http://dx.doi.org/10.1002/ejoc.200900173

23. Lipshutz, B. H.; Wilhelm, R. S.; Floyd, D. M. J. Am. Chem. Soc. 1981, 103, 7672-7674. http://dx.doi.org/10.1021/ja00415a055

24. Miyake, Y.; Wu, M.; Rahman, M. J.; Kuwatani, Y.; Iyoda, M. J. Org. Chem. 2006, 71, 61106117. http://dx.doi.org/10.1021/jo0608063

25. Leroux, F.; Hutschenreuter, T. U.; Charriere, C.; Scopelliti, R.; Hartmann, R. W. Helv. Chim. Acta 2003, 86, 2671-2686. http://dx.doi.org/10.1002/hlca.200390217

26. Krasovskiy, A.; Tishkov, A.; del Amo, V.; Mayr, H.; Knochel, P. Angew. Chem. 2006, 118, 5132-5136; Angew. Chem. Int. Ed. 2006, 45, 5010-5014.

http://dx.doi.org/10.1002/anie.200600772

27. Cahiez, G.; Chaboche, C.; Mahuteau-Betzer, F.; Ahr, M. Org. Lett. 2005, 7, 1943-1946. http://dx.doi.org/10.1021/o1050340v

28. Narender, N.; Srinivasu, P.; Kulkarni, S. J.; Raghavan, K. V. Synth. Commun. 2002, 32, 2319-2324. http://dx.doi.org/10.1081/SCC-120006002

29. Sheldrick, G. M. Acta Cryst. A 2008, A64, 112-122. http://dx.doi.org/10.1107/S0108767307043930

30. Sheldrick, G. M. SADABS-2012/1, Göttingen, Germany, 1996. 